\title{
sciendo
}

DOI 10.2478/sbe-2020-0014

SBE no. 15(1) 2020

\section{INTRA-AFRICAN TRADE, MACROECONOMIC CONDITIONS AND COMPETITIVENESS IN AFRICA}

\author{
OSUJI EMEKA
}

Pan Atlantic University, Lagos

\begin{abstract}
:
More than ever before, trade and regional integration have become two important arguments in the development equation of most modern states and, probably, explains the current rise in regional integration around the world. However, regional integration will not produce optimal benefits in the absence of favourable macroeconomic conditions and substantial internal trade among the integrating members. This paper employs descriptive statistics and econometric techniques to analyze the competitiveness of the continent by studying the impact of relevant intraAfrican trade indices on the competitiveness of Africa, based on a panel dataset spanning 2000 to 2016. The results show considerable variations in both inter- and intra-regional trade performance and competitiveness among African regional groupings and nations. Intra-African trade, especially in exports, over the study period, was consistently low. While the South Africa region had the highest intra-regional trade in imports, East Africa region had the highest level of inter-regional imports. West Africa, with Nigeria's dominance, had the highest level of intra-regional exports, while South Africa had the highest inter-regional exports at country level. For the Regional Economic Communities (RECs), SADC reported the highest intra-African import trades, while SACU reported the highest inter-regional imports. SADC has the highest intra-African exports, while COMESA has the highest inter-regional exports. African Competitiveness Index (ACl) ranking puts the East Africa Region on top, and South Africa as the most competitive African economy. Using panel data covering 2012 to 2016 for 20 African economies, ACl was regressed on a 7-variable model, including intra-regional imports and exports, inflation rate, nominal exchange rate, gross capital formation, and the growth rate of GDP. The results were mixed but plausible. All the variables were correctly signed and significant in different regions, reflecting the huge structural and policy disparities among the regions. Continued transformation of African economies with emphasis on both physical and financial infrastructure, and human capital development will enhance intra-African trade and regional competitiveness.
\end{abstract}

Key words: Economic Integration, Intra- Regional Trade, Macroeconomic Conditions, Competitiveness

\section{Introduction}

Africa needs to enhance its competitiveness in order to sustain its limited development gains. This study focuses on the important role, which increased intra- and 
inter-regional trade, and stable macroeconomic conditions could play to enhance the competitiveness of African states. The current trend is for nations to integrate economically and Africa is part of it. About 44 African countries recently signed the African Continental Free Trade Area (AfCFTA) on March 21, 2018 (Moehr, Coles, \& Tsiknia, 2018), with hope of using it to drive greater competitiveness in the continent. Trade has also been identified as a possible route by which Africa could innovate its way out of its present situation, and promoting intra-African trade through the instrumentality of regional integration is very important [African Development Bank (AfDB), Organization for Economic Cooperation and Development, (OECD), \& United Nations Development Programme (UNDP), 2017; Akorede, 2018)]. One very significant challenge is that the largest economy in Africa, Nigeria, alongside about 9 other countries have not signed the agreement due to concerns over domestic industry protection, labour force considerations, as well as the distribution of the prospective gains (Bello \& Gass, 2018; Moehr et al., 2018; Witschge, 2018). Besides, Africa stands as the continent with the highest number of RECs, but this is not accompanied by substantial trade among members, due to their low levels of competitiveness (Jordaan, 2014).

The current underperformance of intra-African trade is ironical given that an African country belongs to at least 1 REC, while 31 African nations belong to at least 2 RECs (Jordaan, 2014; Geda \& Seid, 2015).Africa features the lowest intra-continental trade as a percentage of total trade standing at $18 \%$, compared to $35 \%$ for Latin America, $45 \%$ for Asia, and 60\% for Europe (Bello \& Gass, 2018). Joordan (2014) reports that Africa exports over $80 \%$ of its output to non-African countries, while importing as much as $90 \%$ of requited items from non-African countries

Kimenyi, Lewis and Routman (2012) emphasize that intra-African trade can boost the competitiveness of African economies via economies of scale and improving the efficiency of firms but empirical evidence on Africa's competitiveness is very scanty. Moreover, the measurement of competitiveness in the few studies that exist for Africa did not use global measures or indicators of competitiveness. Yet, econometric evidence on Africa's competitiveness and its drivers remains a critical piece of information. This study meets these gaps, by adopting the global competitiveness index $(\mathrm{GCl})$ of the sampled African countries as a composite measure of competitiveness capturing several dimensions of national economic wellbeing .

\section{Intra-African Trade, Macroeconomic Conditions and Competitiveness in Africa: Stylized Facts}

\subsection{Intra-African Trade and Macroeconomic Conditions}

The Afreximbank (2017) in its report indicated that intra-African exports and imports performed better in 2016 than it did in 2015. Three main drivers were identified as responsible for the gain in momentum in intra-African trade in 2016 namely. They are Commodity prices; massive trading by some top intra-African traders and enhanced trading within regional economic blocs, and Currency shifts. 
While the above gain in momentum in 2016 is desirable, the entire picture in terms of comparing intra-African trade to other intra-continental trade as well as the growth performance of the intra-African trade shows a bleak picture. In figure 1 below, it can be seen that intra-African trade is dwarfed by volume of intra-continental trade from other regions of the world, especially in Asia, Europe, and North America.

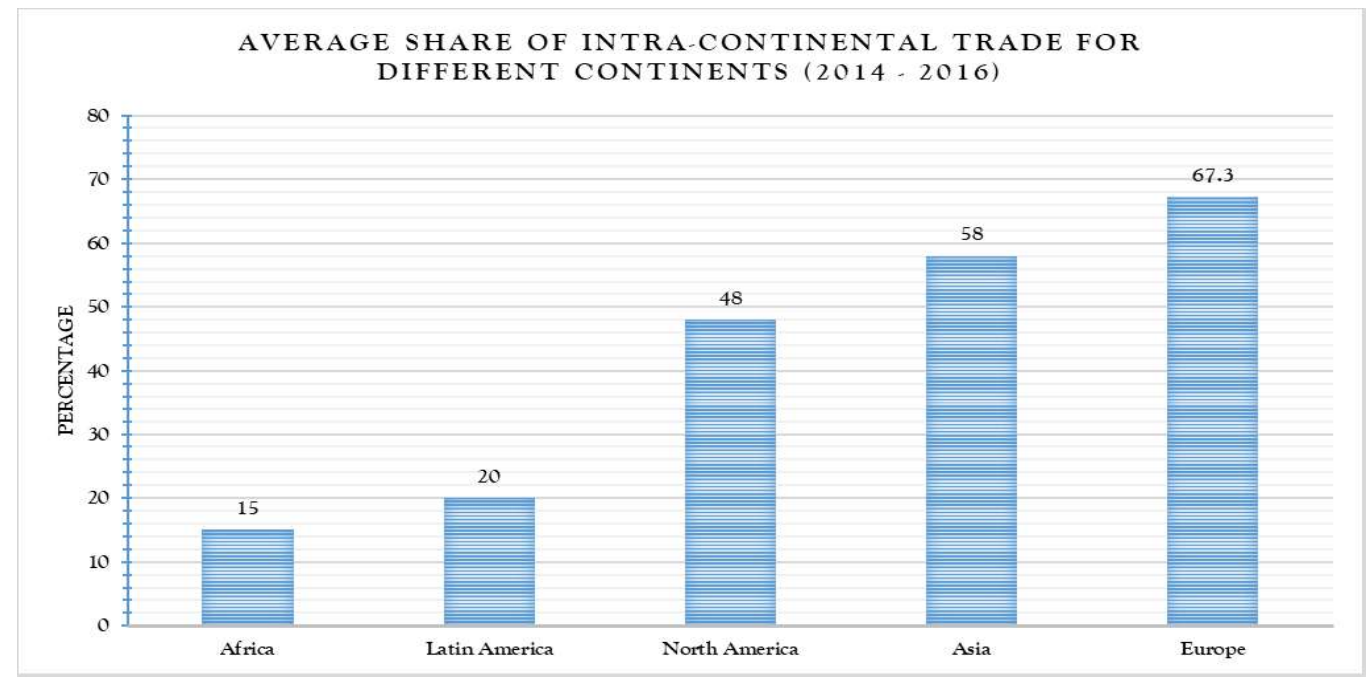

Figure 1: Intra-African Trade Vis-à-vis Other Intra-Continental Trade Source: Afreximbank (2017).

The performance trend of infra-African trade is examined here. Comparison between intra-African trade and non-African trade is also presented here, as well as trade between Africa and emerging and developing economies. Top intra-African traders are also identified. The review period is $2001-2016$ coinciding with the formation of the AU and recent times.

Figures 2 and 3 shows the level of intra-African imports and exports compared to the non-African component. As can be seen for the entire period, both exports and imports within the African countries consistently falls below imports and exports to non-African countries.

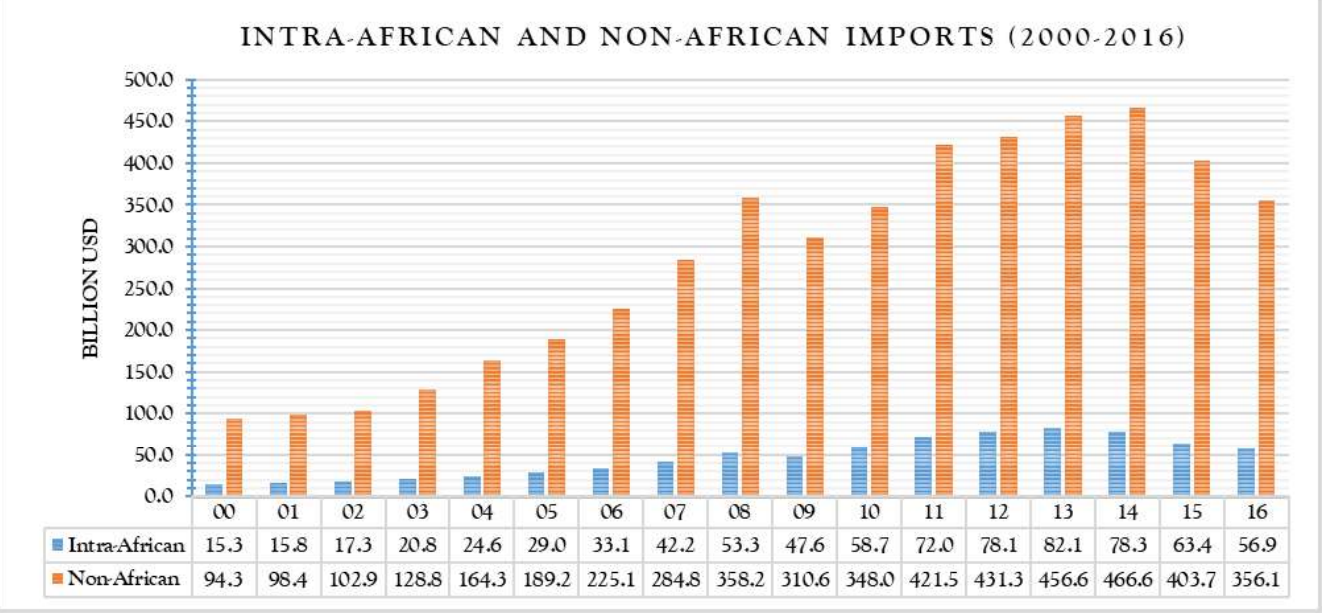

Figure 2: Intra-African Imports Viz-a-viz Non-African Imports

Source: IMF Direction of Trade Statistics (2017). 


\section{Studies in Business and Economics no. 15(1)/2020}

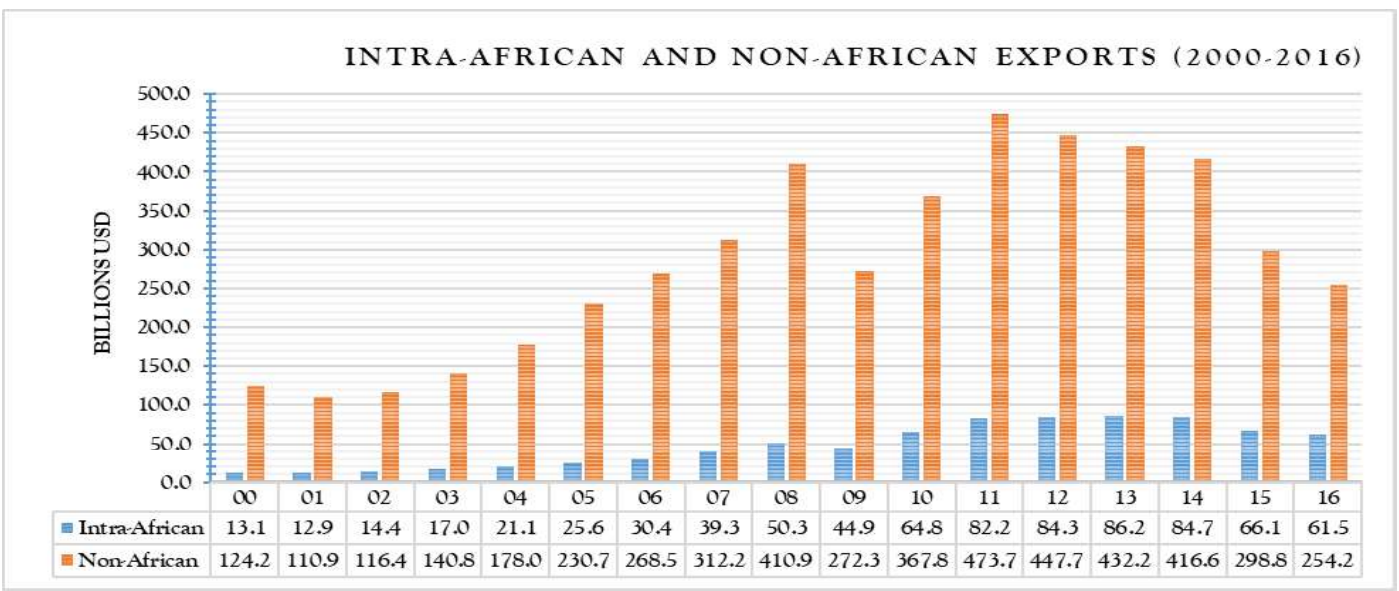

Figure 3: Intra-African Imports Viz-a-viz Non-African Exports

Source: IMF Direction of Trade Statistics (2017).

The absolute figures reported in figures 2 and 3 shows dominance of non-African trade. For exports, the higher exports to non-African countries stems for higher prices that the non-African countries have to offer, as well as better industrial base with huge demand for raw materials that Africa can offer. For the imports, higher imports from non-African countries stems from their weak manufacturing base of most African economies and their high import dependence. Within Africa however, the exports exceed the imports, which is largely as a result of the higher non-African imports explained above. This is shown in figure 4.

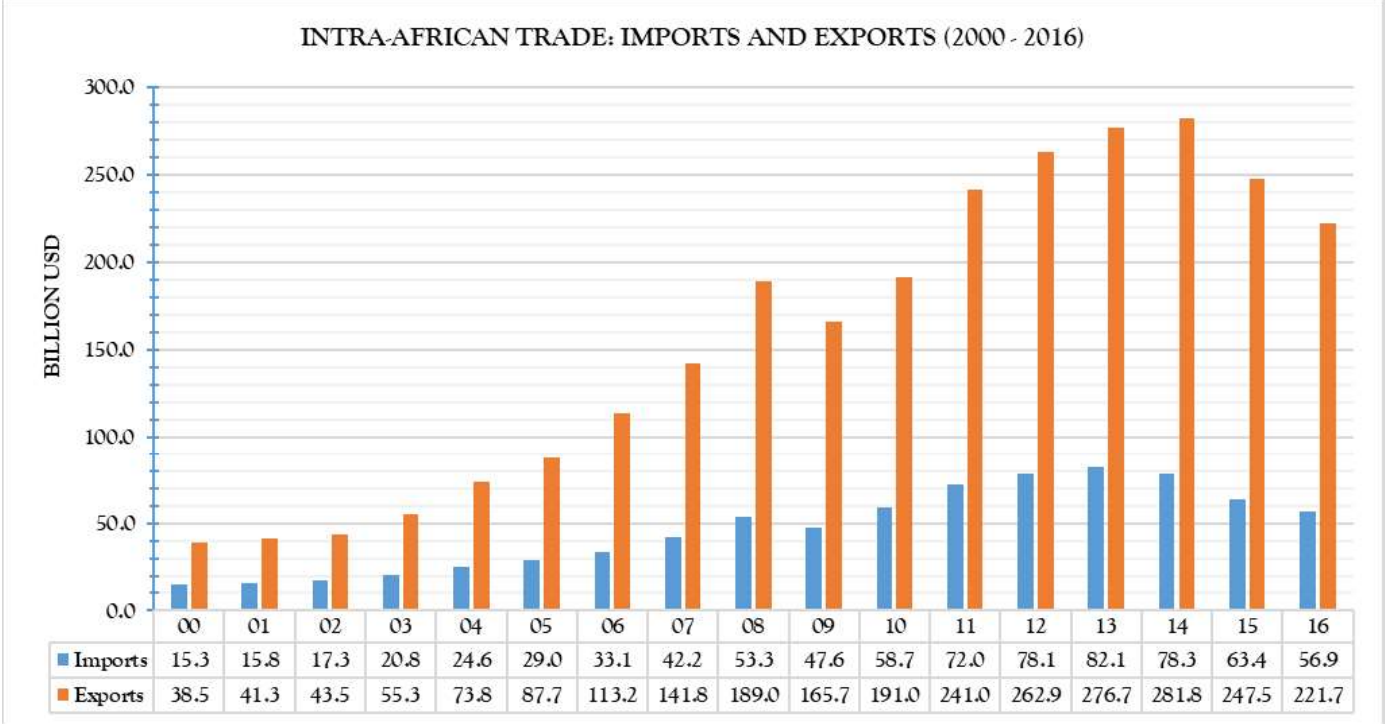

Figure 4: Comparing Intra-African Imports and Exports

Source: IMF Direction of Trade Statistics (2017).

Table 1: Growth Rates of Intra-African and Non-African Trade (2001 - 2016)

\begin{tabular}{|c|c|c|c|c|}
\hline & \multicolumn{2}{|c|}{ AVERAGE IMPORTS } & \multicolumn{2}{c|}{ AVERAGE EXPORTS } \\
\hline Year & Intra-African & Non-African & Intra-African & Non-African \\
\hline $2001-2016$ & 9.50 & 9.57 & 11.50 & 6.87 \\
\hline
\end{tabular}

Source: Author's Computation from IMF Direction of Trade Statistics (2017). 
The growth rates of intra-African and non-African trade shows a quite different picture from the absolute figures reported in figures 2 and 3 . As shown in table 1 , the average growth rate of intra-African and non-African imports for the review period averaged $9.50 \%$ and $9.57 \%$ respectively, while growth rate of intra-African and non-African exports averaged $11.50 \%$ and $6.87 \%$ respectively. As seen, the growth rate of the nonAfrican imports slightly exceeds that of the intra-African imports. In contrast, the growth rate of intra-African exports far exceeds that of non-African exports. This stems from the growing volume of trade between regional economic blocs in Africa, as Africa is increasingly recognizing the imperatives of trading within itself.

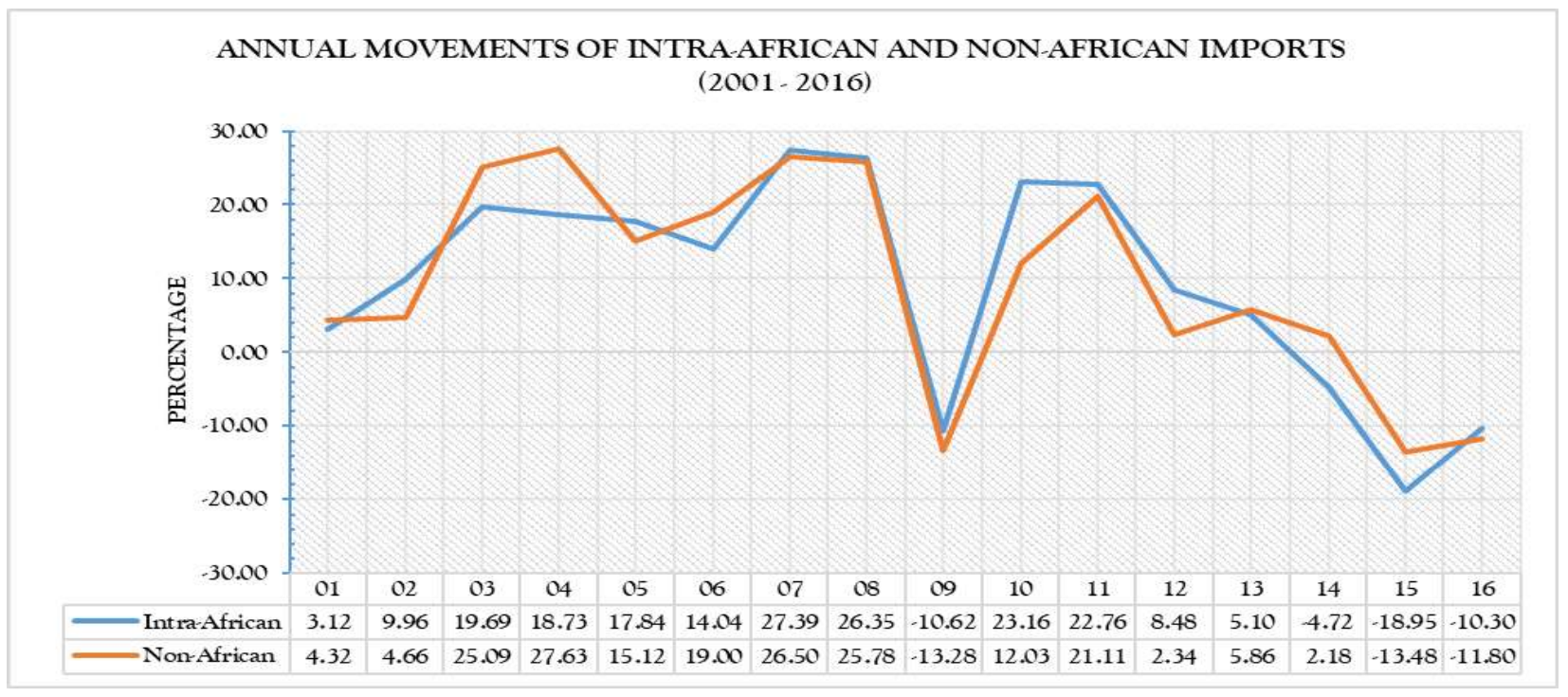

Figure 5: Growth Rates of Intra-African and Non-African Imports

Source: Author's Computation from IMF Direction of Trade Statistics (2017).

Figure 5 shows both intra-Africa and non-African imports declining in 2009, and 2014 - 2016. However, non-African imports had the biggest growth in a single period, growing by $27.68 \%$ in 2004 , compared to the highest growth of intra-African imports of $27.39 \%$ in 2007 . Intra-African imports recoded the most decline of $18.95 \%$ in 2015 , compared to $13.48 \%$ decline in non-African trade in 2015.

Figure 6 replicates same decline patterns for both intra-Africa and non-African exports, declining in 2009, and 2014 - 2016. However, non-African exports recorded the most decline of $33.72 \%$ in 2009 , compared to the highest decline of intra-African trade of $21.94 \%$ in 2015 . Also, intra-African trade recorded the most growth of $44.29 \%$ in 2010 , compared to the highest growth of $35.08 \%$ recorded by non-African exports in 2010 . 


\section{Studies in Business and Economics no. 15(1)/2020}

\section{ANNUAL MOVEMENTS OF INTRA-AFRICAN AND NON-AFRICAN EXPORTS}

(2001-2016)

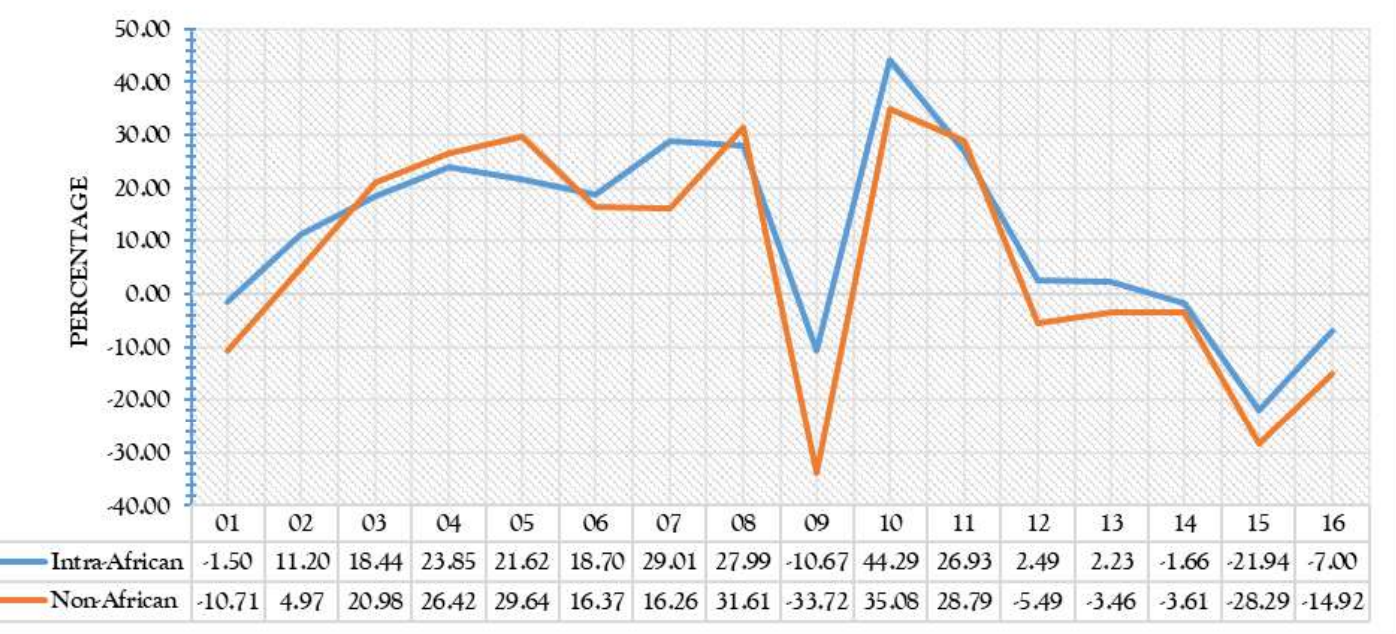

Figure 6: Growth Rates of Intra-African and Non-African Exports

Source: Author's Computation from IMF Direction of Trade Statistics (2017).

The pattern of non-Africa trade delineated between emerging and advanced economies is presented in figure 7 below. The results show two divergent patterns, wherein African trade to emerging economies fell below trade with advanced economies between 2000 - 2011. However, African trade to emerging economies exceeded trade to advanced economies from 2011 - 2016. The rapid industrialization of emerging markets very well explains the change form $2011-2016$.

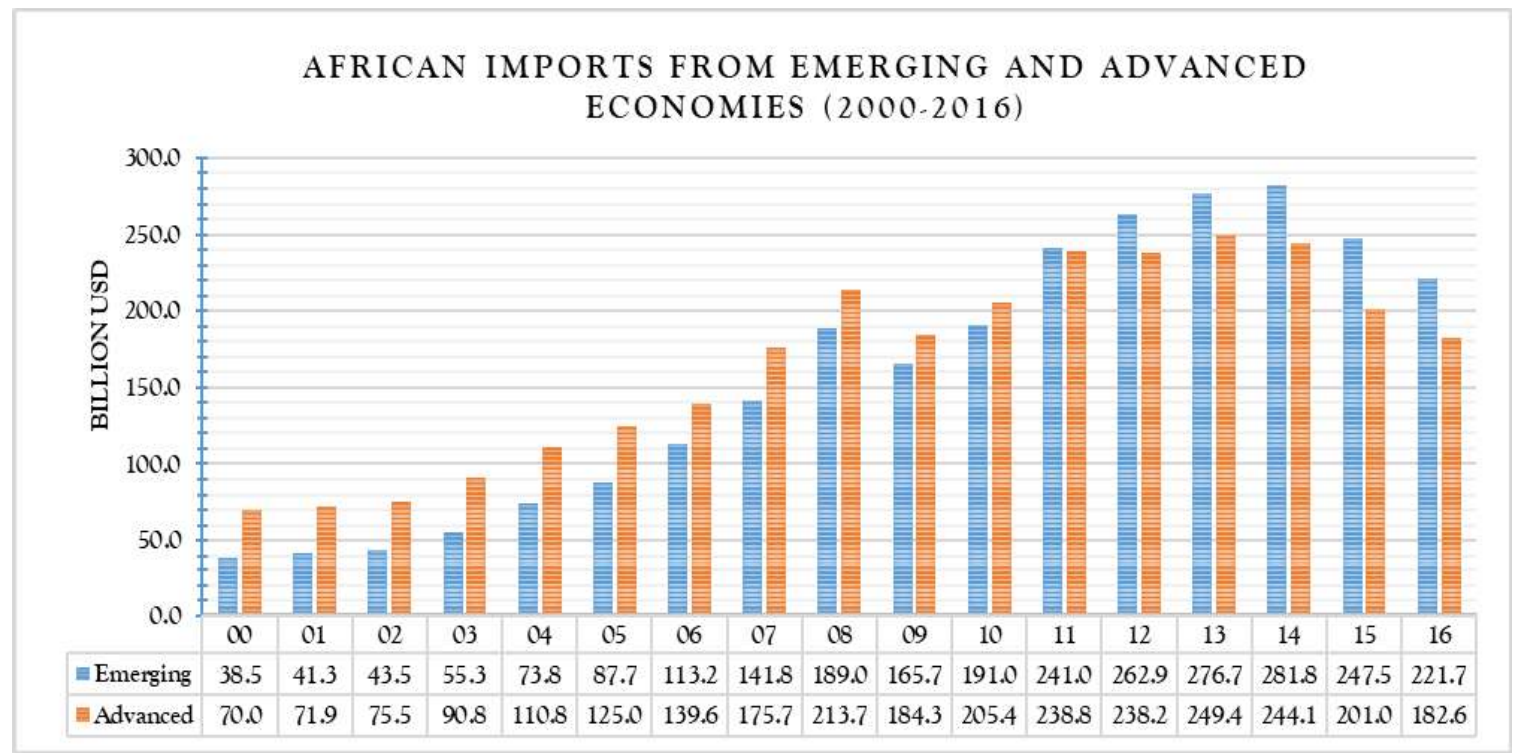

Figure 7: African Trade with Emerging and Advanced Economies

Source: Author's Computation from IMF Direction of Trade Statistics (2017).

Afreximbank (2017) identified the biggest intra-African traders, on the basis of volume of trade between 2014 - 2016, which placed South Africa as the biggest intraAfrican trader, followed by Nigeria and Namibia in $2^{\text {nd }}$ and $3^{\text {rd }}$ places respectively. 
Presented below is the average of the share of these countries' trade in intra-African imports and exports for the period $2000-2016$.

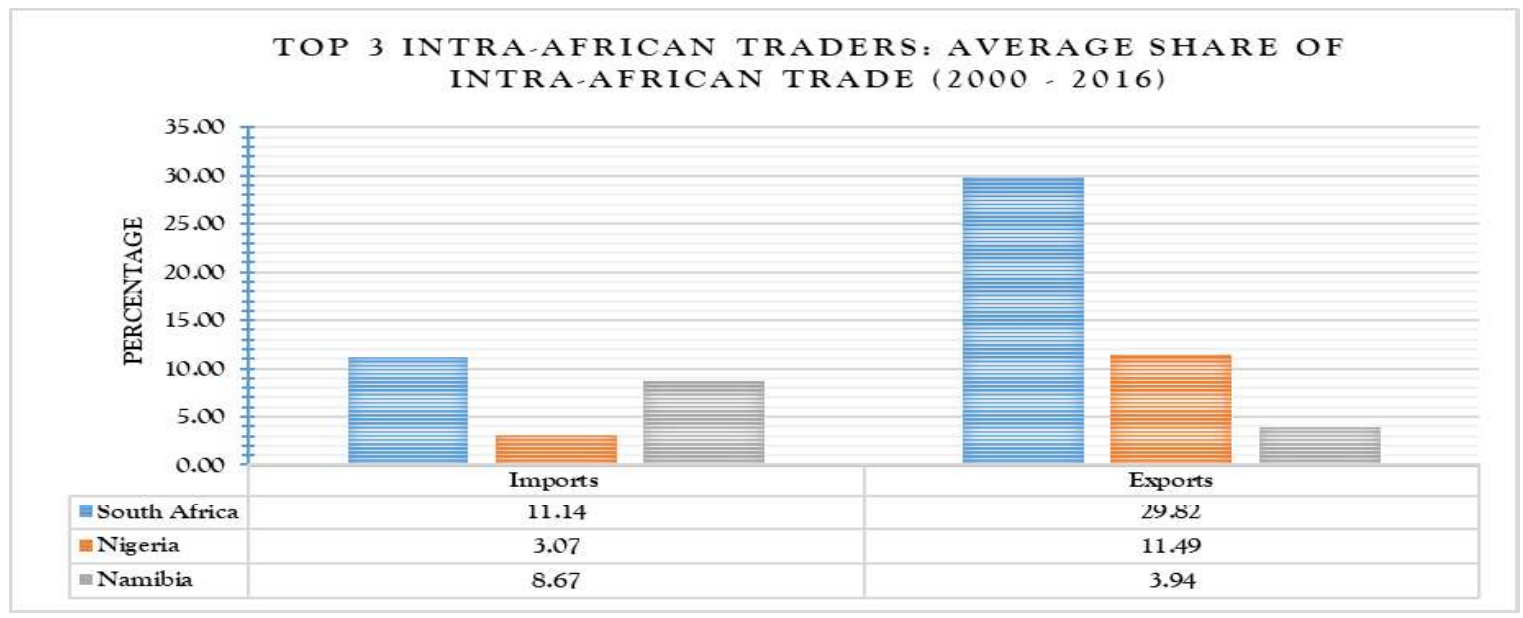

Figure 8: Top Three Intra-African Traders

Source: Author's Computation from IMF Direction of Trade Statistics (2017).

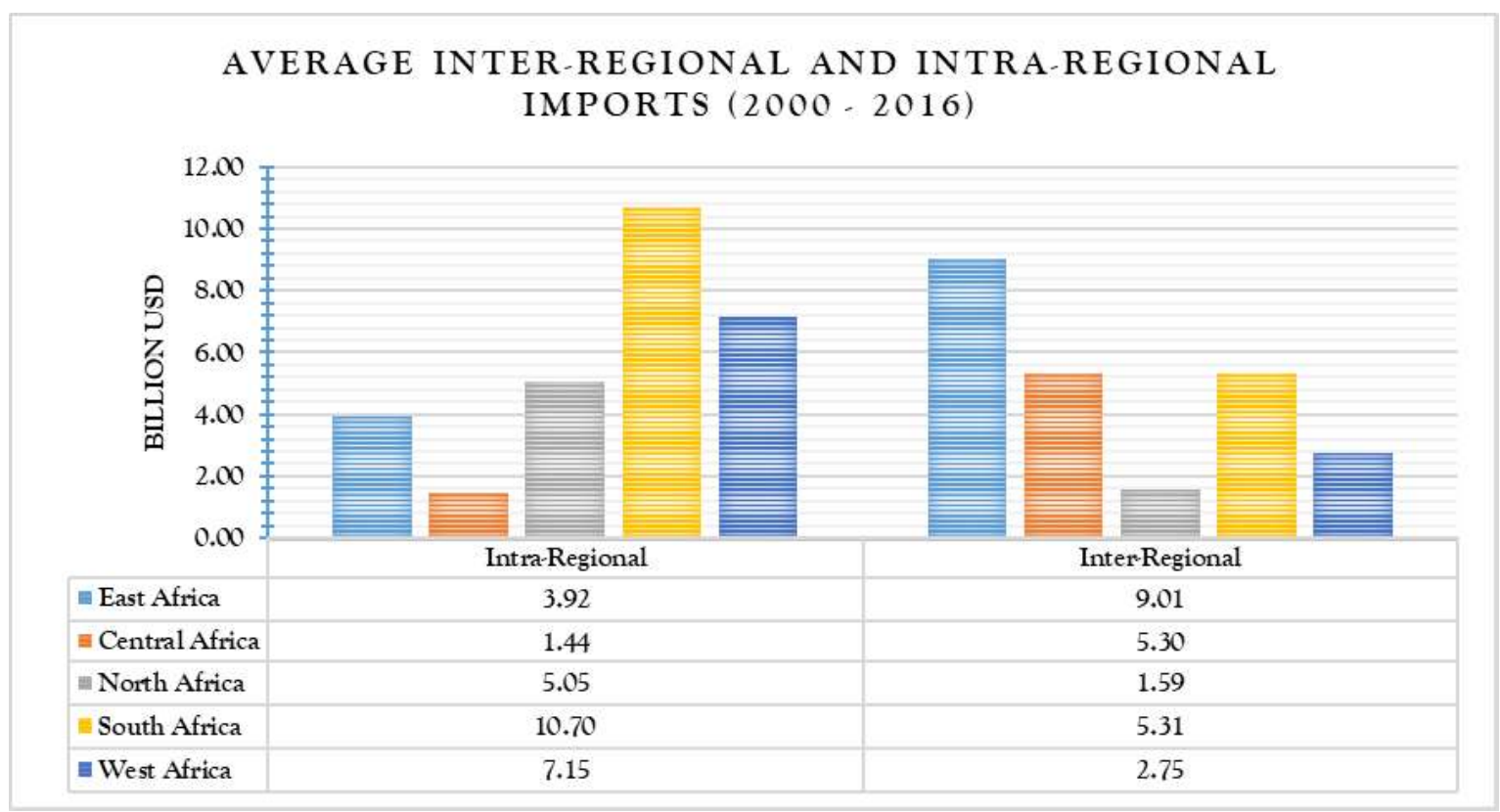

Figure 9: Intra-Regional and Inter-Regional Imports between Regions of Africa

Source: Author's Computation from UNCTAD Stat.

The direction of import trade between the regions of Africa is captured in figure 9 above, which shows that the South Africa region have the highest intra-regional imports, while East Africa has the highest level of inter-regional imports. In figure 10 below, West Africa had the highest levels of intra-regional exports, while South Africa had the highest level of inter-regional trade 


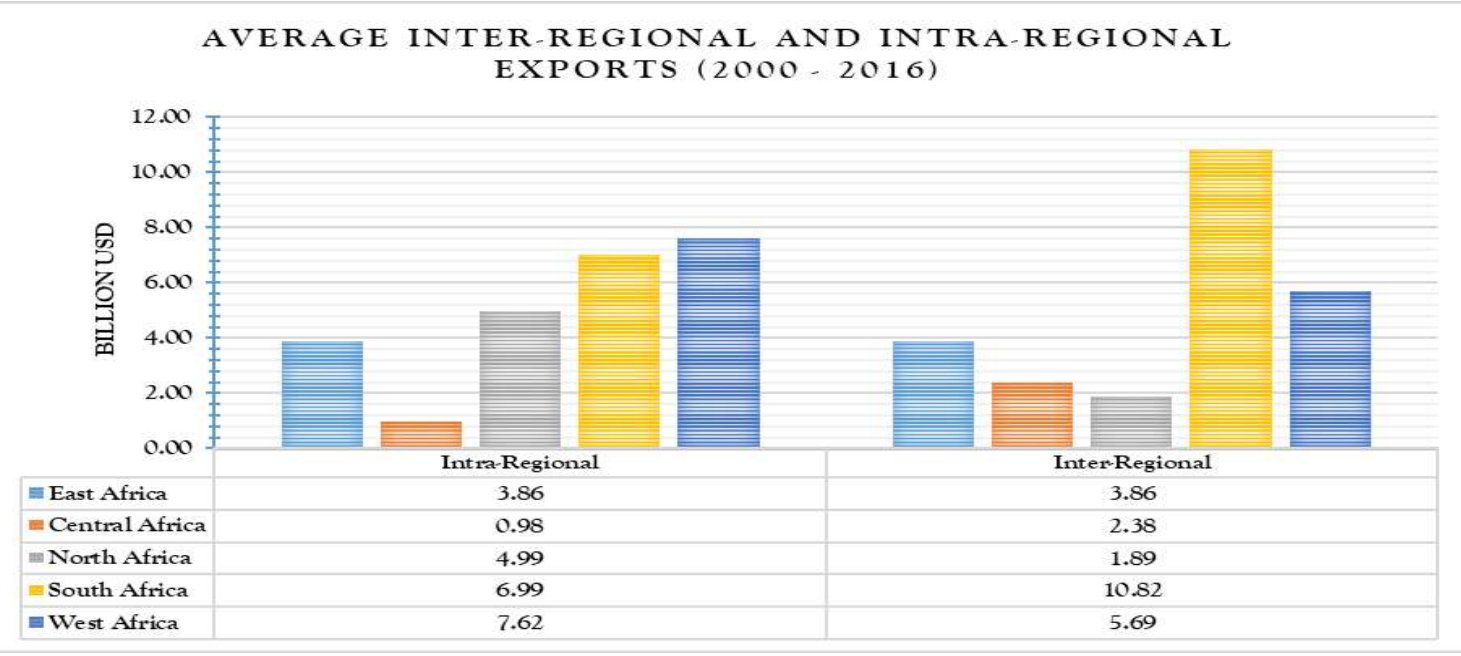

Figure 10: Intra-Regional and Inter-Regional Exports between Regions of Africa Source: Author's Computation from UNCTAD Stat.

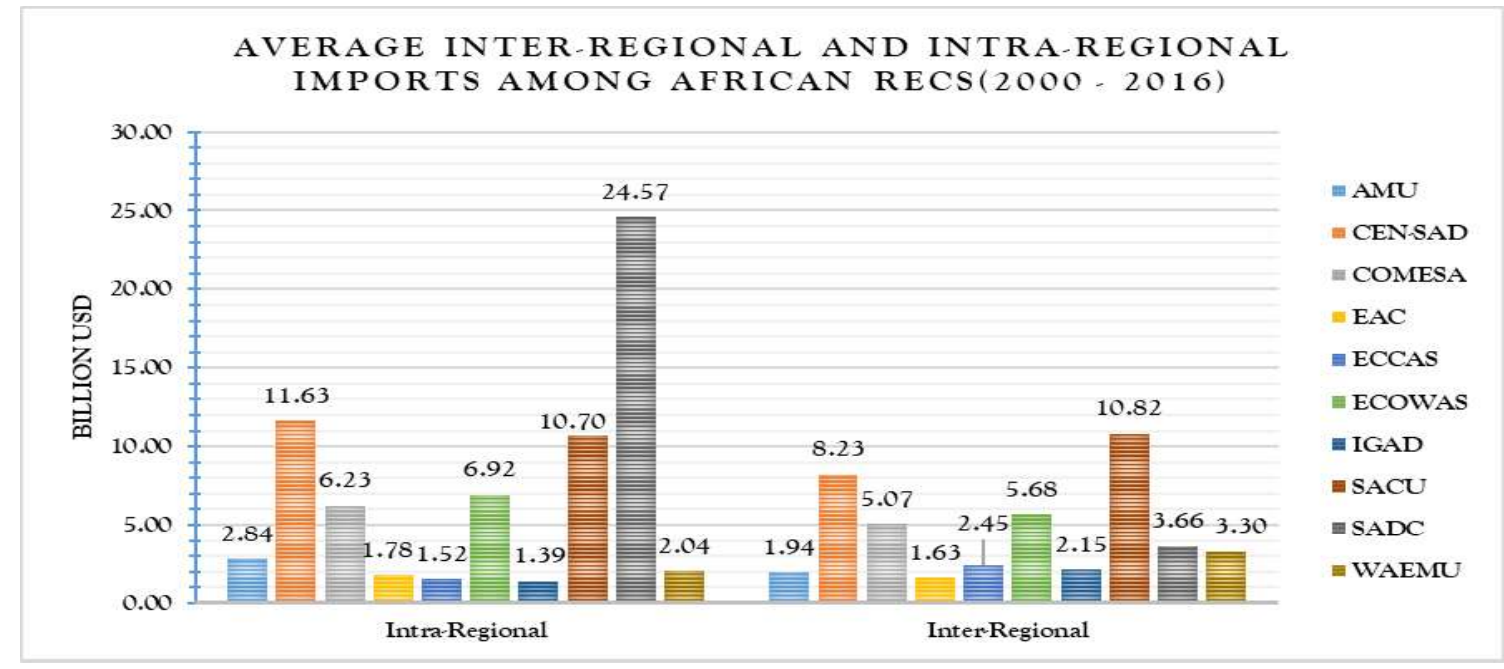

Figure 11: Intra-Regional and Inter-Regional Imports between RECsin Africa Source: Author's Computation from UNCTAD Stat.

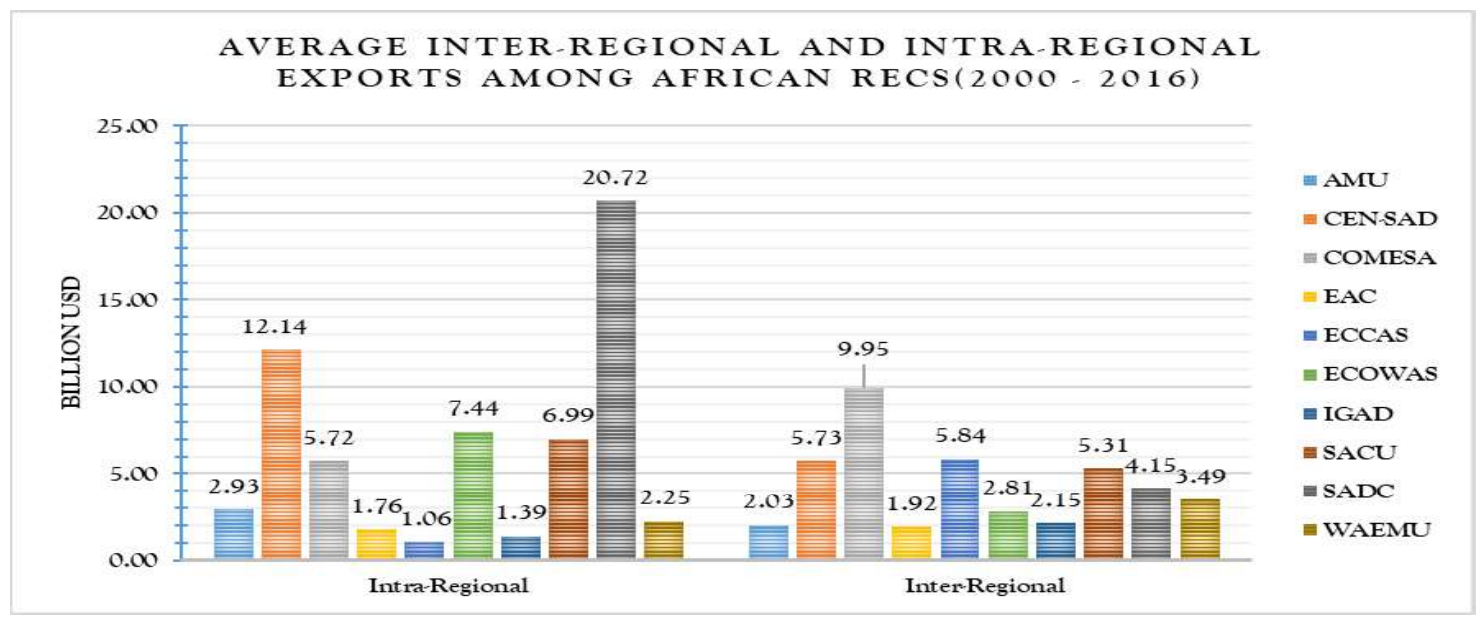

Figure 12: Intra-Regional and Inter-Regional Exports between RECs in Africa Source: Author's Computation from UNCTAD Stat. 
Figures 11 and 12 capture intra-African and inter-African trade among the major regional economic groupings in Africa. The Southern African Development Community (SADC) reported the highest intra-African imports, while the Southern African Customs Union (SACU) reported the highest inter-regional imports. SADC is shown to have the highest intra-African exports, while the COMESA is shown to have the highest interregional exports.

\subsection{Overview of the Competitiveness Performance of AU Member Countries}

The competitiveness of 20AU member countries broadly categorized into the regions is captured in figure 13, wherein the average competitiveness index of all the 4 countries for each region between 2012 and 2016 is obtained and charted below. In figure 13 , it can be seen that East Africa stand as the most competitive region with an average index of 3.835. This is followed by South Africa with an average index of 3.725. The least competitive region is Central Africa, with the lowest average index of 3.345.

Figures 14 through 18 captures the region specific competitiveness rankings for the 4 economies selected in each region. In North Africa, figure 14 captures Morocco as the most competitive economy, and moving up the ranking from 77thposition in 2013 to 70 $0^{\text {th }}$ position in 2016. Both Mauritania and Egypt made steady declines in the global competitiveness index $(\mathrm{GCl})$ rankings. Algeria rose phenomenally in the rankings from 110 in 2012 to 79 in 2014, but dropped to 89 by 2016 .

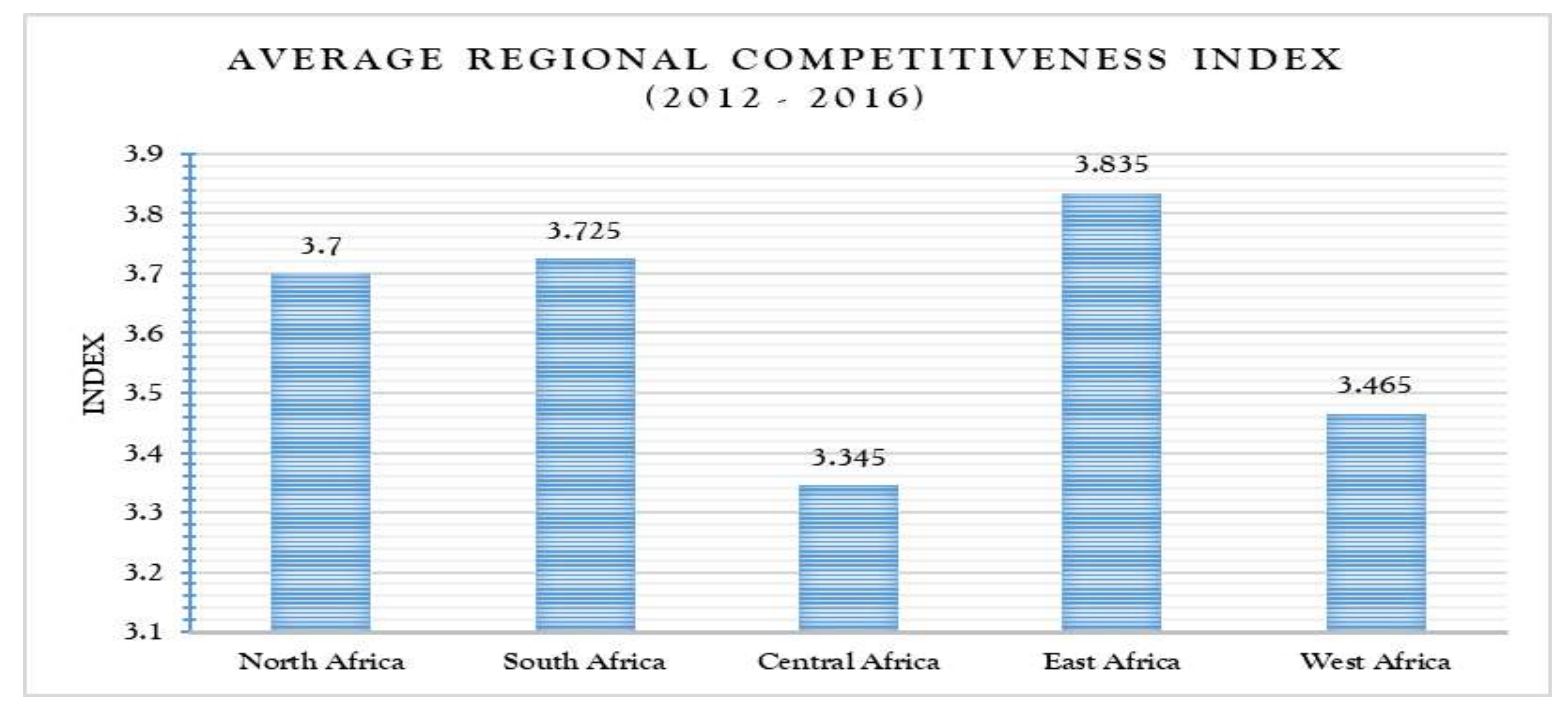

Figure 13: Regional Competitiveness in Africa

Source: Author's Compilation from Global Competitiveness Report (2018). 
Studies in Business and Economics no. 15(1)/2020

\section{GCI RANK MOVEMENTS FOR NORTH AFRICAN COUNTRIES}

$2012 \cdot 2016$

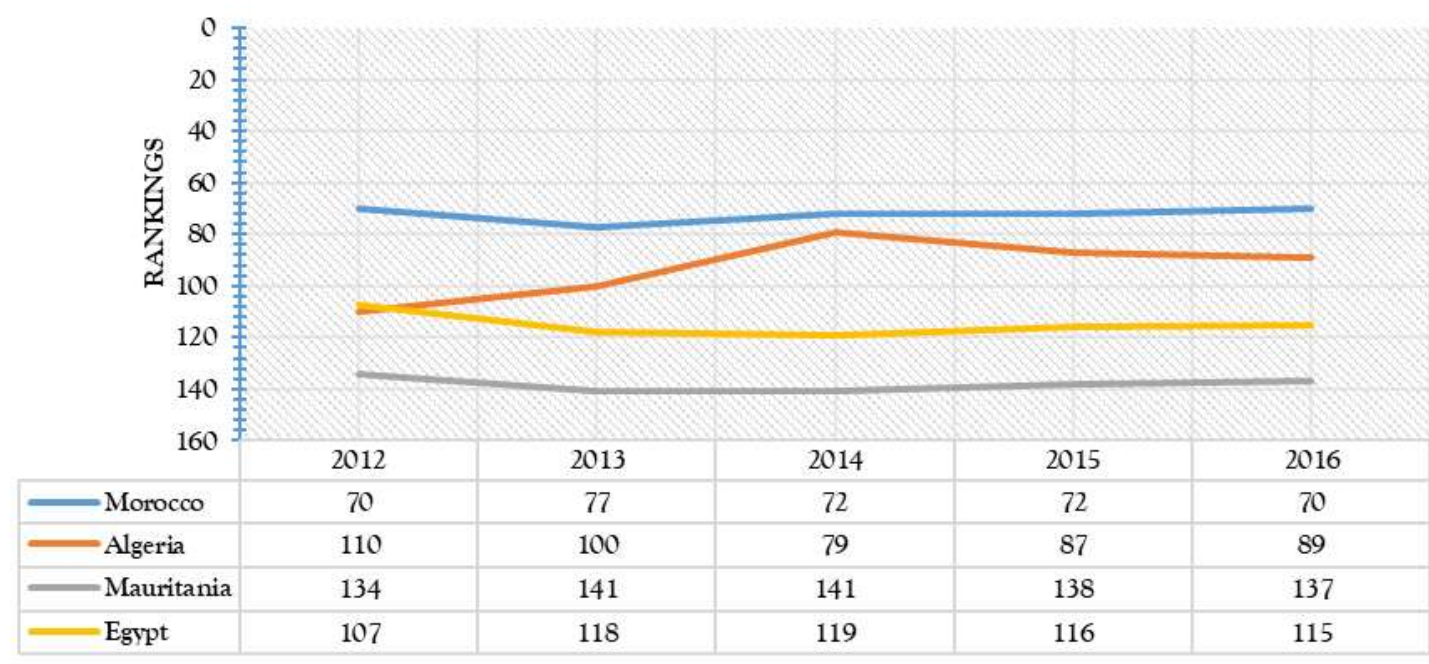

Figure 14: Competitiveness Rankings in North Africa

Source: Author's Compilation from Global Competitiveness Report (2018).

Figure 15 captures the competitiveness performance of 4 economies from South Africa region. South Africa stands as the most competitive economy in this region, though it dropped slightly from 52 on the 2012 rankings to 56 in the 2014 rankings, but made gains on the rankings by moving to 47 on the 2016 rankings. Zimbabwe made some upward movements on the $\mathrm{GCl}$ rankings, from 132 in 2012 to 126 in 2016. Zambia and Malawi fell down the rankings for the review period.

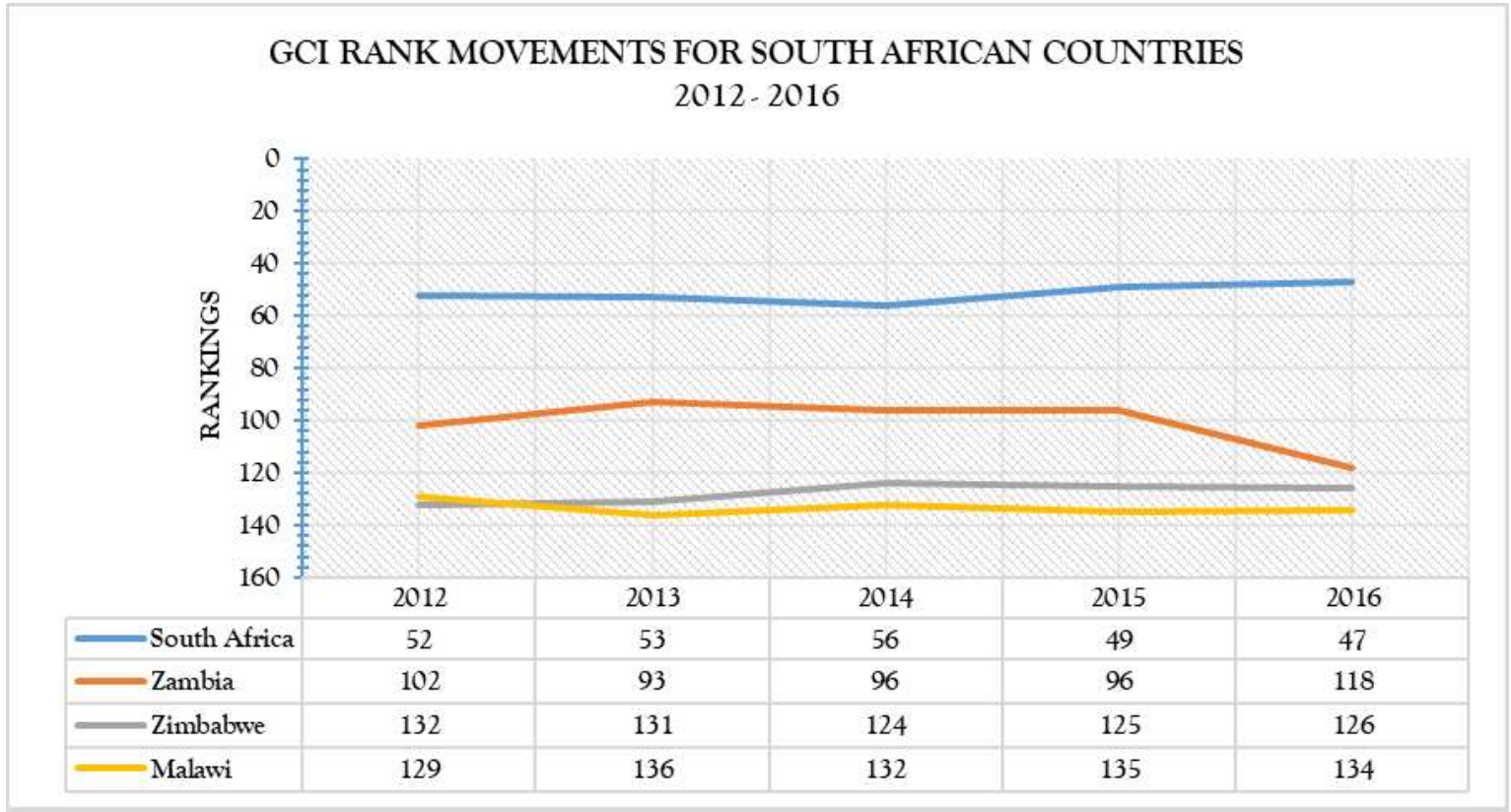

Figure 15: Competitiveness Rankings in North Africa

Source: Author's Compilation from Global Competitiveness Report (2018) 
Studies in Business and Economics no. 15(1)/2020

\section{GCI RANK MOVEMENTS FOR CENTRAL AFRICAN COUNTRIES}

$2012-2016$

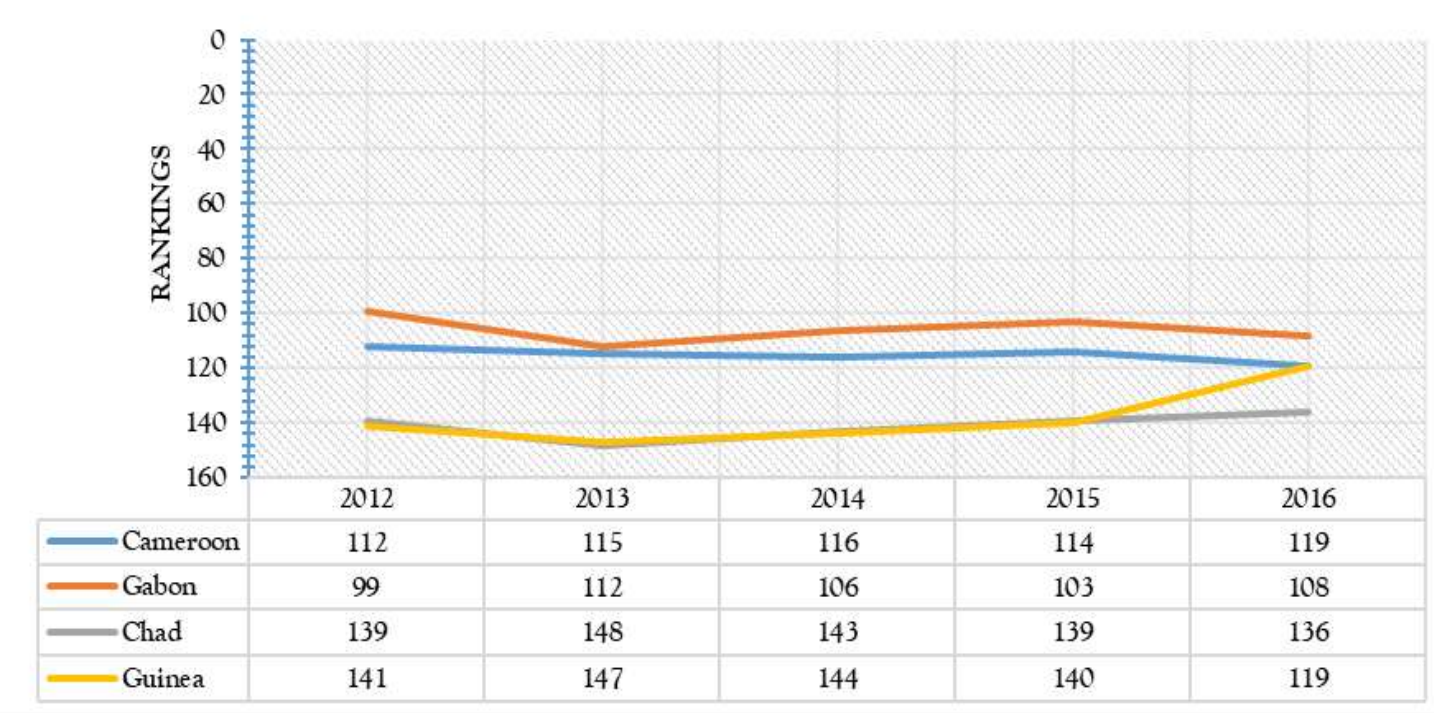

Figure 16: Competitiveness Rankings in Central Africa

Source: Author's Compilation from Global Competitiveness Report (2018)

Figure 16 shows Cameroon as the most competitive Central African economy, though it dropped in the $\mathrm{GCl}$ ranking from 112 in 2012 to 119 in 2016. Gabon declined from 99th position in 2012 to 108th position in 2016. Guinea moved significantly up the rankings from 141 in 2012 to 119 in 2016 . Chad fell by3 places form 139 in 2012 to 136 in 2016.

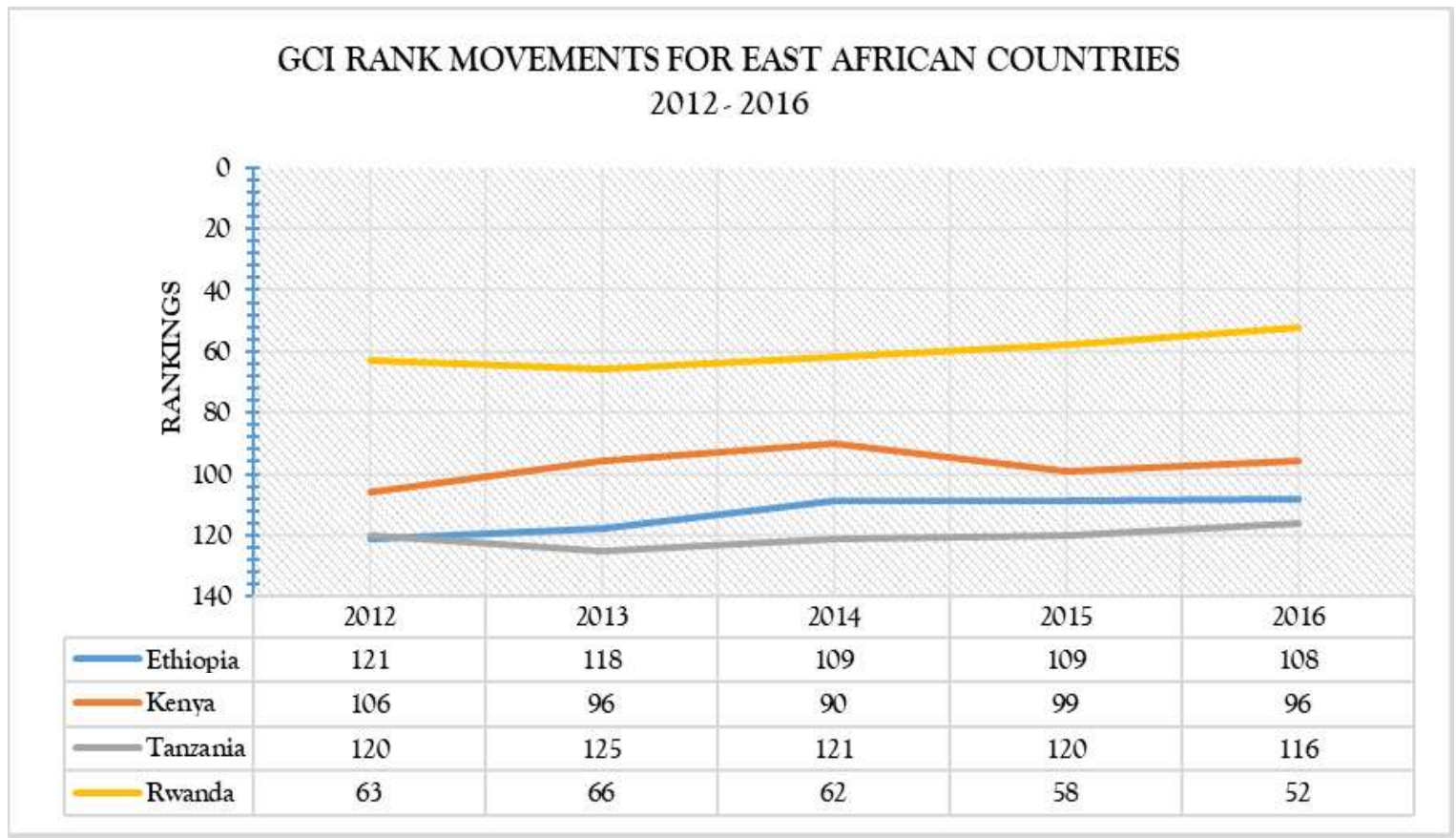

Figure 17: Competitiveness Rankings in East Africa

Source: Author's Compilation from Global Competitiveness Report (2018) 


\section{Studies in Business and Economics no. 15(1)/2020}

GCI RANK MOVEMENTS FOR WEST AFRICAN COUNTRIES

$2012 \cdot 2016$

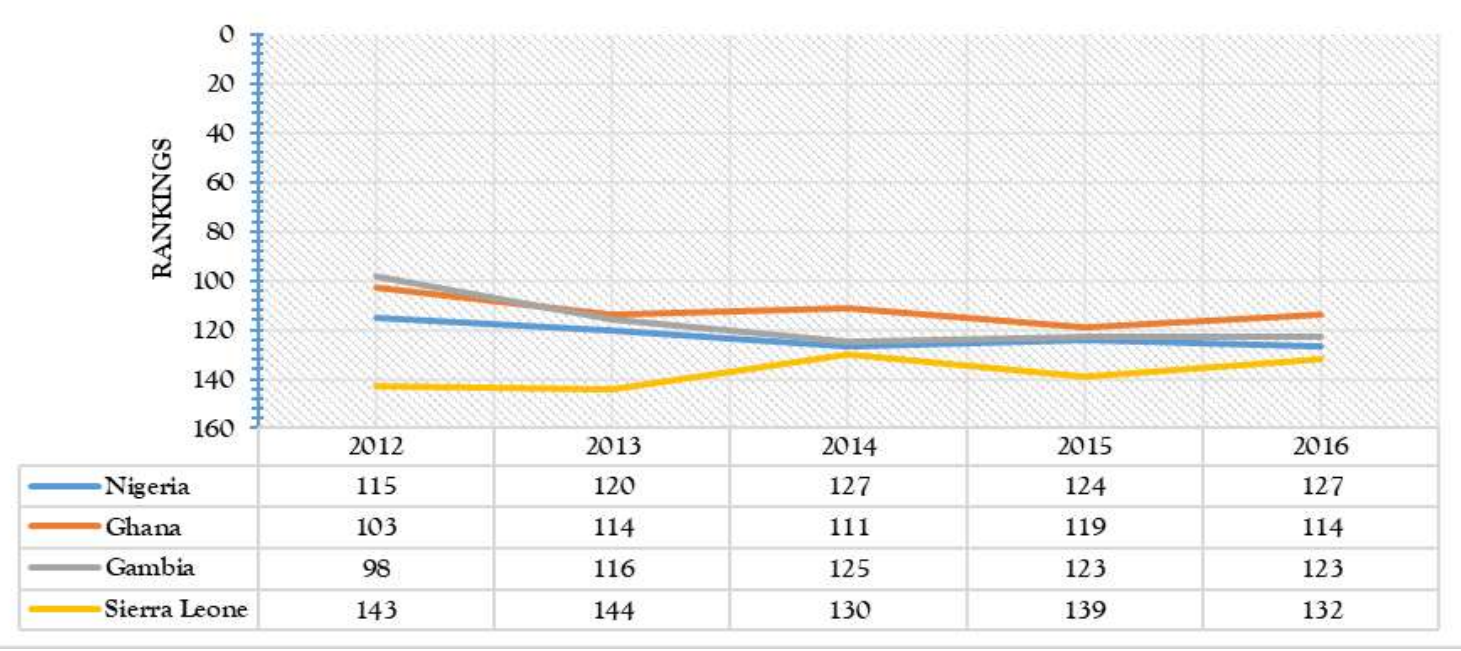

Figure 18: Competitiveness Rankings in West Africa

Source: Author's Compilation from Global Competitiveness Report (2018)

Rwanda is the most competitive East African economy as shown in figure 17 above, and also made some gains on the $\mathrm{GCl}$ rankings, moving from $63^{\text {rd }}$ position in 2012 to the 52nd spot in 2016. Kenya, Tanzania, and Ethiopia all made upward movements in the $\mathrm{GCl}$ rankings. Kenya moved up 10 places from 106 in 2012 to 96 in 2016 . Ethiopia moved 13 places up the rankings from 121 in 2012 to 108 in 2016. Tanzania rose from 120 in 2012 to 116 in 2016.

With the exception of Sierra Leone, figure 18 shows that all other West African countries fell down the GCl rankings. From 143 in 2012, Sierra Leone moved up to 132 in 2016. Nigeria fell steadily from 115 in 2912 to 127 in 2016. Gambia fell steeply from 98 in 2012 to the 123rd spot in 2016. Ghana fell 11 places from the 103rd spot in 2012 to 114 spot in 2016.

The two highest rankings from the 20 African economies dealt with is South Africa (ranked 47 in 2016) and Rwanda (ranked 52 in 2016). Most other economies performed poorly either by being far down the rankings or falling steeply during the period under review. The dismal competitive performance of the AU countries region is not far-fetched, given that the indices with which the competitive index is computed are very bleak for the member countries. Thus, AU countries have performed more poorly compared to other countries resulting from weak and corrupt institutional machineries, huge infrastructural deficits, unfavourable macroeconomic conditions, poor human capital development, inefficient markets, as well as low levels of business sophistication and innovation.

\section{Empirical Review}

The body of empirical evidence on the impact of intra-regional trade and macroeconomic factors on competitiveness, especially for African economies is scanty. What largely exists are anecdotal evidence, without much rigorous analytical depth, and therefore have not adequately measured the direction and magnitude of the impact of 
relevant factors on competitiveness in Africa. Nonetheless, the few existing related studies with some emphases on the subject matter are reviewed. Agbor and Taiwo (2014) examined the determinants of international competitiveness some African economies especially in the Franc Zone. Using a sample of 40 countries for a period of $1980-2011$, pooled OLS model, fixed effects model and random effects model were estimated to capture how competitiveness is determined by 8 variables capturing factor conditions, demand conditions, state of infrastructure, trade intensity, as well as governance. The pooled OLS model showed that domestic demand and factor conditions, as well as infrastructure exerts significant positive impact on competitiveness of African economies, while governance was found to have a significant negative impact on competitiveness of African economies. The random effects model confirmed the above results, but indicated further that FDI exerts a significant positive impact on competitiveness of African economies. The fixed effects model replicated same results as the random effects model.

Rusu and Roman (2018) investigated the determinants of competitiveness of Central and Eastern Europe (C.E.E.) countries using an 8-variable model, estimated using a sample of ten C.E.E countries, and a data set spanning 2004 - 2016. The global competiveness index was regressed on growth rate of the GDP, tax rate, FDI, inflation rate, labour productivity, foreign trade, and cost of business start-up procedure. Empirical estimates from pooled OLS, fixed effects, and random effects models were provided for three groupings of C.E.E. countries grouped into: the Efficiency-driven Economies, Transition economies, and Innovation-driven Economies. For the Efficiency-driven economies, the growth rate of the GDP was found to be an insignificant determinant of competiveness in all three models. Inflation and cost of business startup were found in all three models to have significant negative impact on competitiveness. Tax rate was shown to have a significant negative impact on competitiveness by the fixed effects model; Foreign Trade was shown to have a significant positive impact on competitiveness by the fixed effects model; labour productivity in all three models had significant positive impact on competitiveness while FDI in all three models ha insignificant negative impact on competitiveness.

For the Transition economies, the growth rate of the GDP was shown to have a significant positive impact on competiveness by all three models; the random effects model showed inflation rate to have a significant positive impact on competitiveness; the tax rate exerts a significant negative impact on competitiveness, as shown by the fixed effects model; while all other variables were shown tom have no significant impact on competitiveness. For the innovation-driven C.E.E. economies, the growth rate of the GDP was shown to have a significant positive impact on competiveness by all three models.

Liu and $\mathrm{Xu}$ (2017) examined the national competitiveness implications of educational efficiency using a sample of 53 developed and developing countries for the period 2000 - 2014. For 6 different models, competitiveness rankings from the World Competitiveness Yearbook (WCY) was regressed on educational efficiency, GDP per capita, energy intensity, high-tech exports, employment and population market size. While the first model contained all 53 countries, the other models were adjusted for the level of competitiveness from very strong to very weak. For the first model, educational efficiency was found to have an insignificant negative impact on competitiveness; GDP per capita, 
high-tech exports and employment were found to exert a significant positive impacts on competitiveness; population market size was found to have an insignificant negative impact on competitiveness; while energy intensity was found to have a significant negative impact on competitiveness. For the countries with very weak or weak competitiveness, none of the explanatory variables were found to have a significant impact on competitiveness.

Staehr and Vermeulen (2016) employed the Vector Autoregression (VAR) approach to investigate the impact of competitiveness shocks on macroeconomic performance of 11 OECD countries. Using quarterly data from 1995 (Q1) to 2013 (Q4), four measures of competitiveness were regressed in four separate VAR models on the GDP, current account balance, and domestic credit. The impulse response functions indicated that the GDP seems to be affected more by competitiveness shocks, compared to the current account balance and domestic credit. In particular, it was found out that GDP declines for up to years when there is a worsening of the competitive parameters of an economy.

Latja (2015) investigated the relationship between trade balance and competitiveness of West Balkan economies. Data for 5 countries for the period of $2011-$ 2013 on the global competitiveness index ( $\mathrm{GCl})$, its pillars, and trade balance was subject to the Pearson correlation analysis. A correlation coefficient of $0.6057(p<0.05)$ was obtained, showing that there is significant strong positive correlation between $\mathrm{GCl}$ and trade balance. Results for the pillars indicated that there is a significant very strong positive correlation between trade balance and both goods and market efficiency $(r=0.9380 ; p<$ $0.05)$, and business sophistication ( $r=0.8801 ; p<0.05)$. Trade balance was captured to have a significant strong positive correlation with both labour market efficiency $(r=0.7541$; $p<0.05)$ and efficiency enhancements $(r=0.6196 ; p<0.05)$. Health and primary education, technological readiness, and innovation were all shown to have very weak or weak correlations with the trade balance.

Hchaichai and Ghodbane (2014) empirically investigated the determinants of international competitiveness for Morocco, Tunisia, and Egypt. A data set spanning 1995 2010 was used to estimate an 8-variable model where exports (proxy for competitiveness) regressed on gross capital formation, nominal exchange rate, FDI, education expenditure, R\&D expenditure, high-tech exports, and taxes of international trade. The fixed-effects estimate was the only model reported in the study, and it showed that education expenditure, R\&D expenditure, and FDI all exert significant positive impact on competitiveness, while nominal exchange rate exerts a significant negative impact on competitiveness of the North African countries.

Mutunga (2014) investigated how macroeconomic indicators of the Kenyan economy affect sustainable competitive advantage in the food and beverage sector. The OLS estimation method was applied to primary data generated from a field survey, wherein sustainable competitive advantage was regressed on inflation, bank lending rate, and exchange rate. Preliminary analysis with the Pearson correlation analysis indicated no significant association between sustainable competitive advantage and the explanatory variables, with interest rate in particular having a negative correlation with sustainable competitive advantage. Main results from the regression analysis indicated that none of the 
macroeconomic factors exerts a significant impact on sustainable competitive advantage, with exchange and lending rates having negative impacts.

Masmoudi and Charfi (2013) examined the export competitiveness of Tunisia, with respect to macroeconomic factors. Using annual data spanning 1980 - 2011, a 9-variable model was estimated with the OLS, with the volume of exports as the predicted variable. The results showed that the export competitiveness of Tunisia is significantly increased by increases in custom duties on imports, high-tech imports, fixed capital formation, research and development spending, and free trade with the EU. In contrast, export competitiveness of Tunisia is significantly decreased by increases in real effective exchange rate and inflows of foreign direct investment.

Ulman (2013) examined implications of corruption for national competitiveness, while considering the stage of development of the country. In a cross-sectional analysis involving 3 separate models, the study employed both the Pearson correlation and OLS estimation method to see the relationship between a country's global competitiveness index ( $\mathrm{GCl}$ - dependent variable), and its corruption perception index (CPI - predictor) for 73 countries divided into 2 groups - the factor-driven group (with 38 countries), and the innovation-driven group (with 35 countries). Data was obtained from the Global Competitiveness Index 2012-2013 and the Corruption Perceptions Index 2012. In the first model involving 106 non-grouped countries, the results indicated that strong positive correlation between improving corruption perception of a country and its national competitiveness. The regression estimates indicated that an improving corruption perception has a significant positive impact on the national competitiveness.

The researchers are only aware of the empirical output of Abgor and Taiwo (2014) focusing on 40 African countries, and Hchaichai and Ghodbane (2014) who studied international competitiveness for Morocco. Egypt and Tunisia. Some other studies have studied competitiveness at the national levels (see Mutanga, 2014; Masmoudi \& Charfi, 2013). Thus, empirical evidence on the implications of intra-African economic realities for their competitiveness is lacking. These are some of the research gap the study intends to fill.

\section{Data and Methodology}

Following Agbor and Taiwo (2014) on which this study is situated, we specify the econometric models between Africa's Competitive Index and some of its macroeconomic determinants in the selected countries, and regions of Africa. An all-Africa global model will be estimates along with five others for each other regions of Africa, to determine the relationship that may exist among these countries' and regions' trade indices and their competitiveness, including Imports, Exports, Inflation, Exchange Rate, Gross Capital formation and Real GDP growth rate. The empirical equation for estimation is given as:

$A C l{ }_{i t}=\beta_{0}+\beta_{1} E X P_{i t}+\beta_{2} I M P_{i t}+\beta_{3} I N F_{i t}+\beta_{4} N E X R_{i t}+\beta_{5} G C F_{i t}+\beta_{6} R G D P G R_{i t}+\mu_{i t}$

Where,

$\mathrm{ACl}$ : Africa competitiveness index of a region or country in a given year; 
EXP: intra-African exports of a country or region in a given year;

IMP: intra-African exports of a country or region in a given year;

INF: inflation rate of a country or region in a given year;

NEXR: nominal exchange rate of a region or country in a given year;

GCF: gross capital formation of a region or country in a given year;

RGDPGR: growth rate of the real GDP of a region or country in a given year.

The above model is estimated using panel data from 20 African economies for the period of $2012-2016$. The 20 economies were chosen on the basis of availability of data on their global competitiveness rankings and from the 5 geographical regions in Africa. Morocco, Algeria, Mauritania, and Egypt were selected from North Africa. South Africa, Zimbabwe, Zambia, and Malawi were selected from South Africa. Cameroon, Chad, Gabon, and Guinea were selected from Central Africa. Nigeria, Ghana, Gambia, and Sierra Leone were selected from West Africa. Ethiopia, Tanzania, Kenya, and Rwanda were selected from East Africa

The Ordinary Least Squares regression technique was used to estimate both the global model (for all African countries sampled in the study as a whole), and separately for the 5 regions studied. All analyses were carried out with E-views 10.0. The pooled, fixed effect and random effects models were reported for the global model. However, the adopted model was based on comparing the random-effects and fixed-effects model using the Hausman test. Based on the result of the Hausman test, the F-test or Breusch-Pagan LM test will determine if the pooled model is adopted (Torres-Reyna, 2007; Park, 2011). The random-effects model could not be estimated for the regions, as the number of variables exceeded the number of countries sample for each region. Data was sourced from the IMF Direction of Trade Statistics and World Bank Development Indicators for the countries.

\section{Empirical Analysis}

A total of 6 models were estimated using the Poole OLS, Fixed Effect and Random Effect approaches. Table 2 presents the results of the three outcomes for the overall allAfrica model for the 20 sample economies used in the study.

Our choice of the result for interpretation was informed by the outcome of the diagnostic tests we carried out on the Pooled OLS, Fixed Effects and Random Effects (only for the overall model) models we estimated, to enable us to select the most appropriate models. In choosing between the Pooled OLS and the Random effects outcomes for the all Africa model, the Hausman Test $(p>0.05)$ indicates that the randomeffects model is more appropriate than the fixed effects model. Comparison between the random-effects and the Pooled OLS models, the Breusch-Pagan LM Test $(p<0.05)$, shows that the random effects model is the more appropriate. Nonetheless, we present all the results in Table 2. 
Table 2: Pooled OLS, Fixed-Effects and Random-Effects Models for the Global Model on Intra-African Trade and Macroeconomic Determinants of Competitiveness

\begin{tabular}{|c|c|c|c|}
\hline \multirow{2}{*}{ Variables } & \multicolumn{3}{|c|}{ All Africa Model $(n=20)$} \\
\hline & Pooled Model & Fixed-Effects Model & Random-Effects \\
\hline Constant & $3.501054^{* *}$ & $3.639612^{\star *}$ & $3.583577^{\star *}$ \\
\hline EXP & 0.000555 & 0.017899 & 0.026040 \\
\hline IMP & 0.042634 & -0.040363 & -0.037313 \\
\hline INF & $-0.013747^{*}$ & -0.001810 & -0.001777 \\
\hline NEXR & $1.002985^{*}$ & 0.213742 & 0.243542 \\
\hline GCF & $0.004049^{*}$ & 0.001476 & 0.002703 \\
\hline RGDPGR & 0.004724 & -0.001211 & -0.001573 \\
\hline $\mathbf{R}^{2}$ & 0.342918 & 0.940246 & 0.078190 \\
\hline F-statistic & $7.654255^{\star *}$ & $45.89479 * *$ & 1.244053 \\
\hline \multicolumn{4}{|c|}{${ }^{*} p$-value of $t$-value of coefficient and F-statistic $<0.05$} \\
\hline \multicolumn{4}{|c|}{$\begin{array}{c}\text { Hausman Test: Chi Square Statistic }=5.833952 ; p=0.4420 \\
\text { Breusch-Pagan LM Statistic: } 312.9281 ; p=0.0000\end{array}$} \\
\hline
\end{tabular}

Source: author's computation

\section{The All Africa Model}

From the results, both intra-African exports (EXP) and imports (IMP) were found not to exert any significant impact on the competitiveness of African countries, with imports found to be negative. The insignificant positive impact of exports supports the finding of insignificant positive impact of trade openness on the international competitiveness of African economies by Agbor and Taiwo (2014). This result is also in accord with that of the random-effects model estimated by Rusu and Roman (2018), which returned an insignificant positive impact of trade on the international competitiveness of efficiencydriven Central Eastern European (C.E.E.) countries, though there was a significant positive impact of trade on the competitiveness of innovation-driven C.E.E. countries. The insignificant negative impact of imports obtained comes close to the finding of insignificant negative impact of trade on the competitiveness of transition C.E.E. countries. The result for the innovation-driven economies is instructive and underscores the importance of technology and innovation in the competitiveness of nations.

Inflation (INF) as expected had a negative but insignificant impact. This comes close to the findings of the random-effects model by Rosu and Roman (2018) of a significant negative impact of inflation on the international competitiveness of the efficiency-driven C.E.E economies. It however conflicted with the findings of significant positive impact of inflation on the competiveness of transition-and-innovation-driven economies. The nominal exchange rate (NEXR) was found to have an insignificant positive impact on competitiveness, which is opposite of the findings of Hachaichi and Ghodbane (2014) of a significant negative impact of exchange rate on competitiveness of selected North African countries. Gross capital formation (GCF) was found to have an insignificant positive impact on competitiveness. This plausible outcome is close to the findings of Hachaichi and Ghodbane (2014) of a positive impact of gross capital formation on competitiveness of selected North African countries, though not statistically significant. The Growth rate of the real GDP was found to have an insignificant negative impact on the 
competitiveness of African economies, which is opposite the results of Rosu and Roman (2018) of a significant positive impact of GDP growth rate on the competitiveness for the transition and innovative-driven CEE economies. This result also conflicts the findings of Liu and Xu (2017) of a significant positive impact of GDP per capita on the competiveness of 53 countries. The result might not be unconnected with the quality of growth we have in Africa, which is mostly not shared among the population.

The estimated random-effects model for Africa was able to explain $7.82 \%$ of the variations of in competitiveness. The overall significance of the model was poor as shown by the F-value of 1.244053, which was not significant at both the 0.05 and 0.01 levels of significance. The fixed effects and pooled OLS models however featured better results, as shown on table 2. We associate the seeming poor explanatory power of the model to the data challenges experienced in this study. The weak or poor impact of macroeconomic variables on competitiveness indicates the important role effective policy regimes could have on Africa's competitiveness.

\section{Regional Results}

Results of the five separate models estimated for the five African regions, using a sample of 4 countries for each region are interpreted subsequently. Random effects model could not be run for the regions due to data challenges.

\section{North Africa}

The F-test on table 3 shows a p-value of 0.1508 , indicating that the pooled model is appropriate.

Intra-African exports and imports were found to have insignificant negative impacts on competitiveness of North African economies. Nominal exchange rate, gross capital formation and growth rate of the real GDP were all found to have insignificant positive impact on the competiveness in the region, while inflation was found to have an insignificant negative impact.

Table 3: Pooled OLS and Fixed-Effects Models for North Africa000

\begin{tabular}{|c|c|c|}
\hline \multirow{2}{*}{ Variables } & \multicolumn{2}{|c|}{ North Africa Model } \\
\cline { 2 - 3 } & $2.789510^{* *}$ & Fixed-Effects Model \\
\hline Constant & -0.163527 & $3.164137^{* *}$ \\
\hline EXP & -0.068944 & -0.056067 \\
\hline IMP & $-0.067094^{* *}$ & -0.130535 \\
\hline INF & $7.137586^{* *}$ & -0.029999 \\
\hline NEXR & $0.017229^{* *}$ & 5.172665 \\
\hline GCF & $0.091292^{*}$ & 0.006036 \\
\hline RGDPGR & 0.916668 & 0.078710 \\
\hline R $^{2}$ & $23.83366^{* *}$ & 0.949821 \\
\hline F-statistic & \multicolumn{2}{|c|}{$21.03189^{* *}$} \\
\hline \multicolumn{2}{|c|}{${ }^{*} p$-value of $t$-value of coefficient and F-statistic $<0.05$} \\
\hline \multicolumn{2}{|c|}{ F-Test: F Statistic $=2.202346 ; p=0.1508$} \\
\hline
\end{tabular}

Source: author's computation. 
The estimated random-effects equation explained $94.98 \%$ of the variations in competitiveness of the countries on the North African region, with F-statistic of 21.03189 confirming the overall significance of the model.

Table 4: Pooled OLS and Fixed-Effects Models for South Africa on Intra-African Trade and Macroeconomic Determinants of Competitiveness

\begin{tabular}{|c|c|c|}
\hline \multirow{2}{*}{ Variables } & \multicolumn{2}{|c|}{ South Africa Model } \\
\hline & Pooled Model & Fixed-Effects Model \\
\hline Constant & $3.506005^{\star *}$ & $4.131319^{\star *}$ \\
\hline EXP & 0.084481 & -0.026006 \\
\hline IMP & -0.069226 & 0.035428 \\
\hline INF & -0.008726 & -0.016216 \\
\hline NEXR & 1.218800 & -1.072320 \\
\hline GCF & -0.007578 & -0.004074 \\
\hline RGDPGR & -0.009045 & -0.006075 \\
\hline $\mathbf{R}^{2}$ & 0.969284 & 0.976583 \\
\hline F-statistic & $63.37121^{\star *}$ & $46.33707^{\star *}$ \\
\hline \multicolumn{3}{|c|}{$\begin{array}{l}{ }^{*} p \text {-value of } t \text {-value of coefficient and F-statistic }<0.05 \\
{ }^{* *} p \text {-value of } t \text {-value of coefficient and F-statistic }<0.01\end{array}$} \\
\hline \multicolumn{3}{|c|}{ F-Test: $F$ Statistic $=1.038973 ; p=0.4169$} \\
\hline
\end{tabular}

Source: author's computation.

\section{South Africa}

The F-test on table 4 shows a p-value of 0.4169 , indicating that the pooled model is appropriate for the South Africa Region. Intra-African exports exerts an insignificant negative impact on competitiveness of South African economies, just like in the North Africa Region. Intra-African imports was found to have insignificant positive impacts. None of the macroeconomic variable had a significant impact on the competitiveness of the region. This result is similar to the findings of Liu and $\mathrm{Xu}$ (2017) whose estimation results for weak and very weak competitive economies showed that none of the macroeconomic variables significantly impacts their competitiveness. However, the overall significance of the model was confirmed by the F-value of 46.33707 , which explained $97.66 \%$ of the variations of the competitiveness of countries in the region. As in North Africa the insignificance of macroeconomic variables on Africa's competitiveness again underscores the need for economic policy reforms.

\section{Central Africa}

The F-test on table 5 shows a p-value of 0.0000 , indicating that the fixed-effects model is appropriate. In this region, intra-African exports returned a significant negative impact on the competitiveness of the region. Intra-African imports exerted a significant positive impact on competitiveness. 
Table 5: Pooled OLS and Fixed-Effects Models for Central Africa on Intra-African Trade and Macroeconomic Determinants of Competitiveness

\begin{tabular}{|c|c|c|}
\hline \multirow{2}{*}{ Variables } & \multicolumn{2}{|c|}{ Central Africa Model } \\
\cline { 2 - 3 } & $1.825507^{*}$ & \multicolumn{1}{|c|}{ Fixed-Effects Model } \\
\hline Constant & $2.513423^{* *}$ & $-0.519036^{*}$ \\
\hline EXP & -0.330316 & $0.248639^{*}$ \\
\hline IMP & -0.003098 & $0.014536^{* *}$ \\
\hline INF & 614.0192 & -23.19927 \\
\hline NEXR & -0.086162 & $-0.067853^{*}$ \\
\hline GCF & 0.040730 & 0.005795 \\
\hline RGDPGR & 0.780216 & 0.996689 \\
\hline R $^{2}$ & $4.733218^{*}$ & $225.7911^{* *}$ \\
\hline F-statistic & \multicolumn{2}{|c|}{${ }^{*} p$-value of -value of coefficient and F-statistic $<0.05$} \\
\hline \multicolumn{2}{|c|}{ F-Test: F Statistic $=196.16099 ; p=0.0000$} \\
\hline
\end{tabular}

Source: author's computation.

Both inflation and gross capital formation were found to be the macroeconomic variables was found to have a significant impact (positive and negative respectively) on the competitiveness of Central African economies. The estimated fixed-effects model was able to explain $99.67 \%$ of the variations in competitiveness of the region, with the overall significance of the model confirmed by the F-statistic of 225.7911 being significant at the alpha level of 0.05 .

Table 6: Pooled OLS and Fixed-Effects Models for West Africa on Intra-African Trade and Macroeconomic Determinants of Competitiveness

\begin{tabular}{|c|c|c|}
\hline \multirow{2}{*}{ Variables } & \multicolumn{2}{|c|}{ West Africa Model } \\
\hline & Pooled Model & Fixed-Effects Model \\
\hline Constant & $3.579523^{\star *}$ & $4.093341^{* *}$ \\
\hline EXP & 0.050343 & 0.018597 \\
\hline IMP & $-0.511929^{\star}$ & $-0.323135^{*}$ \\
\hline INF & -0.007791 & -0.025727 \\
\hline NEXR & $1.267138^{* *}$ & 0.349544 \\
\hline GCF & 0.006977 & -0.007396 \\
\hline RGDPGR & 0.004640 & 0.001837 \\
\hline $\mathbf{R}^{2}$ & 0.793020 & 0.939256 \\
\hline F-statistic & $8.301352^{\star *}$ & $17.18074^{\star *}$ \\
\hline \multicolumn{3}{|c|}{$\begin{array}{l}{ }^{*} p \text {-value of } t \text {-value of coefficient and F-statistic }<0.05 \\
{ }^{* *} p \text {-value of } t \text {-value of coefficient and F-statistic }<0.01\end{array}$} \\
\hline & -Test: F Statisti & \\
\hline
\end{tabular}

Source: author's computation.

\section{West Africa}

The F-test on table 6 shows a p-value of 0.0000 , indicating that the fixed-effects model is appropriate. In the West African region, intra-African imports was found to have a significant negative impact on the competitiveness of the countries, while intra-African exports was found to exert an insignificant positive impact on competitiveness of West African countries. Again, although the estimated model explained $93.93 \%$ of the variations 
in competitiveness of the West African region, none of the macroeconomic variables significantly positively impacted competitiveness. The F-value of 17.18074 confirmed the significance of the model at both the 0.01 and 0.05 alpha levels.

\section{East Africa}

The F-test on table 6 shows a p-value of 0.0149 , indicating that the fixed-effects model is appropriate. The results indicate that intra-African exports exert insignificant positive impact on the competitiveness of East African economies, while intra-African imports exerts a significant negative impact. Nominal exchange rate was found to be the only macroeconomic variable significantly impacting competitiveness but negatively. The estimated model captured $90.15 \%$ of the variations in competitiveness, while the overall model was found to be significant given the F-value of 19.82555 being significant at both the $5 \%$ and $1 \%$ levels of significance.

Table 7: Pooled OLS and Fixed-Effects Models for East Africa on Intra-African Trade and Macroeconomic Determinants of Competitiveness

\begin{tabular}{|c|c|c|}
\hline \multirow{2}{*}{ Variables } & \multicolumn{2}{|c|}{ East Africa Model } \\
\hline & Pooled Model & Fixed-Effects Model \\
\hline Constant & $4.639885^{\star *}$ & $4.247613^{* *}$ \\
\hline EXP & 0.000834 & -0.061427 \\
\hline IMP & $-0.481275^{\star *}$ & 0.000684 \\
\hline INF & -0.004351 & -0.006116 \\
\hline NEXR & $-13.43256^{\star}$ & -23.29695 \\
\hline GCF & 0.014331 & 0.007312 \\
\hline RGDPGR & -0.026491 & 0.003024 \\
\hline $\mathbf{R}^{2}$ & 0.901480 & 0.963901 \\
\hline F-statistic & $19.82555^{\star *}$ & $29.66871^{\star *}$ \\
\hline \multicolumn{3}{|c|}{$\begin{array}{l}{ }^{*} p \text {-value of } t \text {-value of coefficient and F-statistic }<0.05 \\
{ }^{* *} p \text {-value of } t \text {-value of coefficient and F-statistic }<0.01\end{array}$} \\
\hline & F-Test: F Statis & \\
\hline
\end{tabular}

Source: author's computation.

\section{Conclusion}

A cursory look at several global competitiveness rankings showed that African economies are either not competitive or at a competitive disadvantage. This study has shown the low significance of intra-African trade on the competitiveness of most of the regional groups and by extension, the entire continent. This could be a reflection of the very low levels of trade existing among members. Similarly, the impact of macroeconomic factors on the competitiveness of African economies was also found to be low. Several unfavourable macroeconomic realities of Africa, including wide disparities in policies and economic structures, and policy instability have had dampening effects on its competitiveness, as shown by the fixed effects and random effects models. Same insignificance of variables can be seen in the cases of North Africa, South Africa and East Africa regions. Furthermore, the dominance of primary produce in African exports, and her weak industrial base, which fuel import dependence serviced by ,non-African countries, may have contributed to the weak impact of intra-African trade on their competitiveness. 
There is however, some evidence from the empirical results, which suggest some low levels of significance of the variables in some regions. It is an indication that Africa can significantly improve its competitiveness if appropriate steps are taken. It is recommended therefore, that efforts be made to make the right policy choices, ensure policy consistency and harmonize macroeconomic action even at the Africa Union level.

\section{References}

African Development Bank (AfDB), Organization for Economic Cooperation and Development, (OECD), \& United Nations Development Programme (UNDP) (2017). African economic outlook 2017: Entrepreneurship and industrialization. Paris: OECD Publications.

African Export-Import Bank. (2017). African trade report: Bridging Africa's trade finance gap through domestic resource mobilization. Cairo: Afreximbank.

Agbor, J. A., \& Taiwo, O. (2014). The fundamental determinants of international competitiveness in African countries with special reference to the CFA Franc Zone (Working paper 463). Cape Town: Economic Research Southern Africa.

Akorede, S. (2018, April 20). Shakir Akorede: How a single market would transform Africa's economy. How we Made it in Africa. Retrieved from

https://www.howwemadeitinafrica.com/shakir-akorede-how-a-single-market-would-transformafricas-economy/61303/

Atkinson, R. (2013). Competitiveness, innovation and productivity: Clearing up the confusion. Washington, DC: The Information Technology and Innovation Foundation.

Bello, A. S., \& Gass, J. (2018, April 3). Who are the winners and losers of Africa's new free trade agreement? [Web log message]. Retrieved from

http://www.atlanticcouncil.org/blogs/africasource/who-are-the-winners-and-losers-of-africa-snew-free-trade-agreement

Cann, O. (2017, September 28). What exactly is economic competitiveness? World Economic Forum. Retrieved from https://www.weforum.org/agenda/2017/09/what-is-economiccompetitiveness/

Competitiveness. (2018). In Business Dictionary Online. Retrieved from http://www.businessdictionary.com/definition/competitiveness.html

Economics Online. (2018). Competitiveness. Retrieved from http://www.economicsonline.co.uk/Global_economics/Competitiveness.html

Geda, A., \& Seid, E. H. (2015). The potential for internal trade and regional integration in Africa. Journal of African Trade, 2, 19-50.

Hachaichi, R., \& Ghodbane, S. B. (2014). Empirical analysis of determinants of international competitiveness. International Journal of Business and Social Science, 5(5), 203-209.

Jordaan, A. C. (2014). Regional integration in Africa versus higher levels of intra-Africa trade. Development Southern Africa, 3, 515-534.

Kimenyi, M. S., Lewis, Z. A., \& Routman, B. (2012). Introduction: Intra-African trade in context. In Brookings Africa Growth Initiative (Ed.), Accelerating growth through improved intra-African trade (pp. 1-6). Massachusetts: The Brookings Institution.

Latja, A. (2015). Competitiveness and its influence on the trade balance: A study for the Western Balkan. European Scientific Journal, 11(10), 187-193.

Liu, F., \& Xu, H. (2017). Effects of educational efficiency on national competitiveness based on cross-national data. Education Science, 7(81), 1-12. 
Masmoudi, M., \& Charfi, F. (2013). The macro-economic determinants of export competitiveness of the Tunisian economy in a context of liberalization and crisis. International Journal of Business and Management Invention, 2(7), 36-49.

Moehr, O., Coles, Z., \& Tsiknia, A. (2018, April 12). Africa embraces the promise of free trade [Web log message]. Retrieved from http://www.atlanticcouncil.org/blogs/econographics/ole-moehr-4

Moreno, E. D. (2014, November). The cluster's competitiveness perceived by stakeholders. Paper presented at 17th The Competitiveness Institute Global Conference, Monterrey, Mexico.

Mutunga, S. L. (2014). Perceived effects of selected macroeconomic indicators on sustainable competitive advantage in food and beverage firms in Kenya. European Journal of Business and Management, 6(30), 97-107.

Park, H. U. (2011). Practical guides to panel data modeling: A step by step analysis using Stata. Lecture notes, International University of Japan, Niigata Prefecture.

Rusu, V. D., \& Roman, A. (2018). An empirical analysis of factors affecting competitiveness of C.E.E. countries. Economic Research-Ekonomska Istraživanja, 1480969, 1-16.

Sala-i-Martin, X. (2016, September 28). It matters how competitive your country is. Here are three reasons why. World Economic Forum. Retrieved from https://www.weforum.org/agenda/2016/09/it-matters-how-competitive-your-country-is-hereare-three-reasons-whyl

Schwab, K., \& Sala-i-Martin, X. (2018). The global competitiveness report 2017-2018. Geneva: World Economic Forum.

Siudek, T., \& Zawojska, A. (2014). Competitiveness in the economic concepts, theories and empirical research. Oeconomia, 13(1), 91-108.

Staehr, K., \& Vermeulen, R. (2016). How competitiveness shocks affect macroeconomic performance across euro area countries (Working Paper No. 1940). Frankfurt: European Central Bank.

Torres-Reyna, O. (2007). Panel data analysis: Fixed and random effects using Stata (v .4.2) [Powerpoint slides]. Lecture notes, Princeton University, New Jersey.

The Competitiveness Institute. (n.d.). What is competitiveness? Retrieved from http://www.tcinetwork.org/media/download/1185

The Institute for Management Development (IMD) World Competitiveness Center. (2018). The IMD world competitiveness yearbook 2018. Switzerland: IMD.

The Intra-African Trade Fair. (2018). The rationale for the trade fair. Retrieved from https://www.intrafricantradefair.com/home/intra-african-trade-fair-2018

Ulman, S. (2013). Corruption and national competitiveness in different stages of country development. Procedia Economics and Finance, 6, 150-160.

Witschge, L. (2018, March 20). African continental free trade area: What you need to know. Aljazeera. Retrieved from https://www.aljazeera.com/news/2018/03/african-continental-freetrade-area-afcfta-180317191954318.html 